\title{
What I learned from the Ypsilanti Perry Preschool Project: A teacher's reflections
}

\section{Louise Derman-Sparks}

Abstract: This article, written by one of the teachers in the Ypsilanti Perry Preschool Project (1962-1967), critically examines the prevailing narrative about the preschool project's relationship to the High/Scope Educational Foundation. It describes what the author and other teachers actually did, the principles that informed their practice, and challenges the prevailing myth that the Perry Preschool used the High/ Scope Educational Foundation curriculum. It also discusses what the High/Scope Longitudinal Study did not research about the program, families, and children in the Ypsilanti Perry Preschool and examines possible factors, beyond the curriculum, which effected its positive outcomes. The Perry Preschool Project occurred during the years of the 1960s Civil Rights Movement in the USA, and reflected prevailing ideologies and educational philosophies, some of which were in contention with each other. By bringing the Teachers' voices to the prevailing discussion, which, to date, is dominated by the Project administrators' perspective, the article seeks to open up new thinking about the lessons of the Ypsilanti Perry Preschool Project for both early childhood education pedagogy and research.

Key words: Perry preschool, teacher's voice, myths \& realities, missing research, resilience.

Once, a long time ago, between September 1963-June, 1965, I was one of the teachers in the Ypsilanti Perry Preschool Project (PPP). Then in my 20s, this was my first job after graduate school. Now, I can reflect about my experiences at PPP through the lens of my many years work in early childhood anti-bias education, as a teacher of children and adults, author, consultant, and activist. 
The Perry Preschool Project, 1962-1967, was an early effort in the U.S.A. to explore the potential of early childhood education for fostering the development and school success of children in families living in great poverty. The three and four-year-old African American children attending the Preschool lived in Ypsilanti, Michigan. Most of their families lived in a housing project in the African American segregated neighborhood, across from the segregated public primary school, which housed the Perry Preschool. Heads of families included two-parents, single parents, and, in a few cases, grandparents. Funding first came from local, state, and national governmental agencies. One requirement of funding was that the children have an "Intelligence quotient" (IQ) in the "educable retarded" range, as defined by the Michigan Dept. of Instruction at the time (Weikart et al., 1964). A control group of children was also set up, with demographics parallel to those of the children attending the preschool

The High/Scope Educational Research Foundation's longitudinal study followed both the preschool and control group of children from their preschool years through their forties. It demonstrated that attending the Perry Preschool had a significant impact on the lives of the children and a positive economic impact in relation to the larger society (Schweinhart et al., 2005). These findings have had a major impact on governmental policy in many countries, becoming a major rationale for investing in early childhood programs, especially for children from families living in great poverty.

However, over the years I have been troubled by the misrepresenting of the Perry Preschool as a High/Scope Foundation project using the High/Scope curriculum, and by the prevailing narrative about the factors responsible for the positive longitudinal outcomes of the Perry Preschool Project. For example, a 1964 Progress Report states that the "The Perry Preschool project used what has since been called the High / Scope Curriculum" (Weikart, 1989, p.8). But, the first version of the High/Scope Curriculum (Hohmann, Banet \& Weikart, 1979) first appeared 12 years after the PPP had ended in 1967. Yet in a 2009 publication, the second director of the High/Scope educational research foundation, claims that, "David P. Weikart and his colleagues developed the [High/Scope] model in the 1960s for use in the High/ Scope Perry Preschool program" (Weikart \& Schweinhart, 2009, p. 191).

I also wonder about the factors the High/Scope Longitudinal Study did not research and what these might have contributed to our understanding if they had been investigated. Existing research, while useful, doesn't tell us everything about the Perry Preschool Project. 
In this article I offer an alternative viewpoint about the PPP curriculum. I describe the educational principles and practices that I and other teachers carried out. I also consider factors beyond the curriculum that might have influenced the positive outcomes of the Perry Preschool, despite the fact that the that the High/Scope Longitudinal Study design did not look at them. I end the article with a few thoughts about the links between my PPP experience and my subsequent years writing, teaching and speaking about early childhood anti-bias education.

\section{Social-Political Landscape}

Educational thinking and practice do not emerge in a vacuum. Rather, the social, political, and economic dynamics of a period create a framework for specific pedagogical endeavors. The PPP (1962-1967) was born during the inspiring and demanding years of the 1960s Civil Rights Movement. Racial segregation was still the reality in most institutions throughout the USA, including in the school system. Voting rights were systemically denied to African Americans and other People of Color ${ }^{1}$, especially in the Southern states of the country. While the 1954 Supreme Court decision made intentional school segregation illegal, actual changes in school systems took many years of national and local civil rights movement efforts. Moreover, segregation was not the only factor causing the outrageously disproportionate school failure of African American and other children of color. In Ypsilanti, Michigan - the location of the Perry Preschool Project - longstanding segregation was the rule, and one public school exclusively served the African American community. The Perry Preschool was located in that school.

One aspect of the larger Civil Rights Movement focused on the education system. Among educational theorists and activists committed to building equal opportunity in the schools, debate raged about the underlying causes and most effective strategies. One major group of thought argued for the concept of cultural deprivation and the causal relationship between race and "IQ" (intelligence quotient). They attributed school failure and low IQ scores in low-income African American communities and other low-income ethnic groups, to inadequate parenting, language, and community culture. Their solution was to "fix" children by teaching them the skills they did not get in their families and by teaching low-income families of color (and some

The USA term "people of color" is similar to different terms used in other countries to identify the several groups of people targeted by systemic racism and prejudice. These terms include "Black people" and "ethnic minorities". 
very poor White families) families how to parent (See, for example, Deutsch, 1963).

In contrast, opponents of "cultural deprivation" and of IQ testing challenged the validity of both explanations (See, for example, Harvard Educational Review Reprint Series \#5, 1971). They identified the effects of systemic poverty, and racism, as well as inappropriate and biased teaching methods and teachers, as primary causes of school failure, and argued that children's low IQ scores were manufactured artifacts of the tests. They argued for cultural differences rather than deficits and for bicultural models of education and advocated for an empowering pedagogy that respected children of color as equally intelligent as white children, and schools that respected cultural difference and multiple ways of learning. They called for knowing the strengths of poor families, and families of color and including them as partners in their children's education they proposed that early childhood programs foster children's positive self-concept, sense of efficacy and empowerment, as well as the academic skills needed in later schooling, and offer families skills for navigating the pathways of the school system.

For the most part, Perry Preschool teachers and administrators shared the goals of the civil rights movement and were passionate about ensuring that the children in the program succeed in school. However, disagreements between teachers and administrators reflected the larger debates about the causes of school failure in the larger society. Most of the PPP administrators took the cultural deprivation and IQ perspective, as stated in their 1964 Perry Preschool Progress Report:

The Perry Preschool Project is an experiment to assess the longitudinal effects of a two-year preschool program designed to compensate for mental retardation, which is associated with cultural deprivation.... The specific population of the Perry Preschool Project was defined as... coming from, culturally deprived families, and testing in the range of educable mentally retarded. (Weikart et al., 1971, p.1)

On the other hand, several of the teachers, including me, rejected the validity of the IQ tests for determining the children's true capacity and ability. We also disagreed that the families had insufficient or inadequate culture or needed the teachers to educate them about parenting. These divergent viewpoints about the children and families made for some key differences between what the teachers actually did with the children and families and what demonstrators wrote about the program. 


\section{Perry Preschool Pedagogy and the High Scope Curriculum: Confronting the Myth}

The Perry Preschool did not work from an already developed curriculum. Rather, its pedagogy and curriculum evolved over the program's five years. A "Perry Preschool Curriculum" per se, was never written down. The little we do have appears in a 1964 Perry Preschool Project Progress Report (Weikart et al., 1971), submitted to project funders, and in teacher-written reports about some of the small group, teacher-directed activities (Derman, 196365). An article in Young Children describes the curriculum of the PPP's last two years (Sonquist \& Kamii, 1967).

In a nutshell, the Perry Preschool curriculum and the High Scope Curriculum are not the same. Nevertheless, the myth that the High Scope Curriculum caused the positive outcomes of the PPP has been widely disseminated in the literature. In addition, the project that followed the ending of PPP has also been mistakenly confounded with it. For example, in a final report to the U.S. Department of health, Education, and Welfare, Weikart et al. (1970) wrote that "This report describes the Cognitively Oriented Curriculum based on Piagetian theory which is used in the Perry Preschool Project"(Document Resume). But, PPP no longer existed. Sadly, the distortions about the relationship between the Perry Preschool and subsequent High/Scope projects has distorted discourse about the central elements of quality early childhood education.

What can be said, is that a thread exists from the last two years of the Perry Preschool curriculum to the Cognitively Oriented Curriculum (Weikart et al., 1971), which came out the High/Scope preschool curriculum comparison project that followed the PPP, and then to the first version of High Scope Curriculum (Hofmann et al., 1979). The High Scope curriculum authors were not attempting to document or reproduce what happened in the Perry Preschool, but rather to create a new curriculum, based on High/ Scope foundation projects created after the Perry Preschool Project ended.

PPP's pedagogical principles and methods, especially during its first three years, reflected prevailing early childhood thinking at the time, while also plowing some new ground. From 1963-65, teachers were the primary engine driving the evolution of PPP's curriculum. We met every Friday afternoon to discuss our observations of the children's cognitive, language, and socialemotional behavior during the week, and collaborated on plans about what 
to do next. In years four and five), exploration of the educational implications of Jean Piaget's theory of children's cognitive development became the basis for the curriculum framework (Sonquist \& Kamii, 1967).

\section{Education principles}

The teachers' abiding belief in the children's intelligence and capacity to learn formed the overarching framework of our educational practices, in contrast with project administrators' tendency to view children through the lens of their deficits. We paid attention to the specific cognitive, emotional and physical needs of each child. For example, here are excerpts from two of my small group activities daily reports: "Children seemed to be really listening and understanding the two books I read today --more than usual. Both were made by children in the group" (12/9/1964) (Derman, 19631965), and, "J. is able to take a new role in dramatic play when stimulated with new ideas, Trip to airport provided new material for him" $(1 / 4 / 1965)$ (Derman, 1963-1965). We used children's strengths and already existing knowledge to scaffold learning. We praised children's ideas, even when we also challenged them, worked on their learning school language while never telling a child that their home speech was wrong, held children in our laps, and gave those lots of hugs.

A fundamental belief in the indissoluble relationships between socialemotional and cognitive development was a second overarching educational principle. We believed that emotional well-being and emerging cognitive abilities "are the 'bricks and mortar' of the foundation of human development" (Shonkoff, 2007, p. 1)" While the official position of the Perry Project focused on cognition and downplayed the role of social-emotional dynamics, the teachers did not separate these two fundamental components of development. The teachers' daily interactions with the children were the primary vehicle for fostering social-emotional growth. Occasionally, we also designed specific activities, for either school or home visits (e.g., children making fullsize outline portraits of themselves).

At the same time, we also paid considerable attention to children's cognitive and language development. In years one, two, and three of the Perry Preschool the teachers drew on a variety of cognitive development teaching approaches. Some reflected ECE thinking at the time, such as the "unit method," the organization of the day, and most of the materials. We also used ideas from people such as Maria Montessori, Sarah Smilanksy, and, in the third year, from Irving Siegel and Jean Piaget. The developmental 
and constructivist thinking of Piaget then became the primary pedagogical framework in years four and five. With a generous budget, we could create a rich learning environment, consisting of traditional ECE materials (e.g., picture books, puzzles, board matching games, number games), natural materials gathered by the teachers, and some of Montessori's educational toys.

We believed in children learning through their active engagement with the world, and, to this end, encouraged them to explore their ideas with materials and in social-dramatic play. Knowing that the children's world was mostly limited to their own, segregated community, we also took frequent field trips to explore their neighborhood and neighboring towns. We then used experiences to initiate and further activities. In year one (1962-1963), disagreement arose among the teachers about what balance to create between children-initiated and teacher-directed teaching. The two experienced early childhood educators argued for the former, while the Perry program founder/ director and the two teachers with special education background argued for the later. The resolution was to provide a combination of both.

Last, but not least, creating respectful, two-way learning relationships with families was a fundamental principle for the teachers. Achieving this goal was not easy. At first, the teachers had to prove to the community that we really cared about their children and respected their families-that we were not yet another group of professionals coming into their homes to tell them how they should live their lives. In fact, the first year, when teachers went door to door to inform the community about the program and to recruit children, some families refused to open their doors. By the end of the first year, people wanted their child in the preschool although each new teacher still had to prove him or herself.

My most memorable experience of facing a family member's distrust is this: Feeling very noble because I had agreed to visit one of my families after $6 \mathrm{pm}$, when the parent came home from her work in a commercial laundry, I knocked at the door. Her 15-year-old age daughter opened it and I saw the mother standing at the stove cooking dinner (after standing all day at her job). I also heard her say, "Oh shit! Is she here?" It was certainly a teachable moment for me. I quickly decided to drop what I was supposed to do (have the parent sit down with me at a table for an hour while I worked with her child). Instead, we worked at a table in the kitchen while the mother continued to get dinner ready, and then informally chatted with her. Over time-I visited this family for two years-we built a strong working relationship. 
However, her first words to me are still vivid-and I am glad of that. It was a most effective lesson for a fledgling teacher.

\section{Preschool morning program}

A large block of time was devoted to child-initiated activity time, during which the teachers set up traditional early childhood learning centers (e.g., blocks, art, small-motor manipulatives, dramatic play, book corner, woodworking), based on program goals and our assessment of the children's needs. During activity time, teachers provided individualized scaffolding to children's chosen activities. Small group, teacher-directed teaching also took place every day, often relying on the "unit method" as a strategy for planning specific activities. Content included reading readiness, language development, science and math readiness, as well as frequent field trips to the children's neighborhood and surrounding communities.

The daily morning schedule consisted of children-choice activity time, snacks with informal conversations, small-group teacher-directed activities and outdoor time. Children came to the center for three hours in the morning, and received a $1 \frac{1}{2}$ hour home visit once a week. Four teachers worked as a team with 24 children - a very desirable ratio. In my years at Perry Preschool, two teachers were African American and two White-American, while the children were all African American. Two teachers were experienced and two beginners (including me). Three of us had an early childhood education background and one had special education certification. The diversity of the teachers' backgrounds made possible the sharing of invaluable insights and information.

\section{Preschool afternoon program: Home visits}

Each teacher carried out weekly home visits in the afternoon with the same families throughout school year. Visits lasted 1 to $1 \frac{1}{2}$ hours, and were adapted to the needs of each child, giving teachers a weekly opportunity to work with each child on specific cognitive and school skills as needed. Teachers brought learning materials such as books, crayons, felt pens, and paper, and small manipulatives to work with the child and parents (usually the child's mother). Informal weekly conversations with parents were also an important part of each home visit. These were primarily about the child's week at school, any specific concerns about which we wanted the parent's perspective, parent questions about the preschool child and sometimes about older siblings and their school experiences. Occasionally, a par- 
ent might also raise a concern about dealings with professionals from other social agencies, i.e. a social worker.

Perry Preschool administrators, perceiving families as culturally deprived or culturally disadvantaged and blaming their parenting methods for children's school failures, wanted teachers to correct family's childrearing practices. However, many of the teachers, including me, did not see our role -or our right-as changing childrearing. Rather, we focused on helping families learn ways to support the skills children needed for cognitive development in general, and school skills in particular. Demonstrating specific teaching techniques for supporting their child's general development and learning of basic school skills (e.g., reading, writing, math), we also made clear our faith in each child's intelligence and capacity to learn. We worked hard to create a mutual sharing of information and ideas about their children, eliciting and respecting the strong aspirations and hopes families had for their children. One telling feature of families hopes, were the many homes that had pictures of Dr. Martin Luther King, Jr., and President John F. Kennedy on their living room walls.

I, for one, also shared strategies with parents for managing the school system as advocates for their children, grounded in the principle that this was a right of theirs. Two years of weekly talking with the Perry Preschool teachers provided practice and confidence building for talking with later teachers. I also occasionally went with a parent to the school to meet with a teacher of an older child. Most parents engaged with interest in our home visit sessions.

\section{What the HS Longitudinal Research Did Not Consider}

As with all studies, the data gathered by the High Scope researchers, as well as the research tools they chose to use shaped the research outcomes. While the longitudinal data they did collect has been invaluable for garnering support for early childhood programs, High Scope researchers also ignored potentially equally valuable data. So, beyond the necessity of putting an end to the erroneous attribution of the Perry Preschool outcomes to the High Scope Curriculum, it is useful to consider what data what not gathered in the HS Longitudinal Research.

The three major 'stakeholder" groups were never interviewed about their experiences and perspectives, i.e., the teachers, the families and the Perry Preschool children. Rather, research about the children came from school 
and other institutional records, and from IQ tests, and from the families by pre-and-post questionnaires during the years of the preschool (Weikart et al., 1964). Thus, we do not know about the thoughts about what mattered to them from the three groups directly affected by the PPP.

Given what we know about the complexity of human development and learning, it is perilous to put all our eggs in the basket of any one factor. Instead, we need to be asking questions and developing hypothesis for further research about the multiple potential elements that underlie the research outcomes, based on what we can reestablish about the actual Perry Preschool experience. We also need to take into account our current knowledge base about children's development and learning. Here are some examples of topics for further research and discussion that were ignored in the HS Longitudinal Research Study.

Teacher attitudes: Any curriculum and methods are only as good as the teachers who implement them. My 50 years of professional work since I left Ypsilanti have taught me that the best curriculum and teaching methods are subverted when teachers hold uncovered and unexamined prejudices, misconceptions, or ignorance toward an aspect of a child's multiple identities, e.g., class, race, ethnicity, culture, religion, language, gender, family structure, sexual orientation, ability. These attitudes are difficult to "quantify," but they can be investigated (Rosenthal \& Jacobson, 1968; Rist, 1970; Duffy \& Gibbs, 2013).

Teacher-child relationships: Teachers were never asked about how they viewed the children and their goals and expectations for them. The relationships between the Perry teachers and children were not documented, or discussed either in reports about the program or in the research. However, as many in the ECCE field argue, "The active ingredient in the environment that's having an influence on development is the quality of the relationships that children have with the important people in their lives. That's what it's all about" (Shonkoff, 2001, p. 1).

Home-teacher relationships: The nature of the long-term relationships of the teachers and with families, and their impact on the families, was not investigated through family and teacher narratives. Nor were families asked about how they viewed and they about their children's experiences and development during their two years in the Perry Preschool. Instead, a pre-and-post questionnaire about parents childrearing attitudes and how these changed was the primary research instrument (Radin $\&$ Kamii, 1965). I think I most regret 
the lack of more information about the home visits-what really happened during them and what families felt they gained (or didn't).

Teacher autonomy: Perry teachers practiced what is now called "intentional teaching". We met every Friday afternoon for reflection and planning to foster the balance between child-initiated and teacher-directed activities. We were free to generate curriculum to meet the needs of children within the overall goals of the program. In this regard, we were in line with what is now considered an important component of implementing quality early childhood programs.

\section{Laying a Foundation for Resilience}

Since the time of the Perry Preschool, I have done considerable study, discussion and writing about the importance of children learning to resist the harmful impact of racism (and other "isms") on their social-emotional and cognitive development. The accumulation of innumerable "micro contaminants" of racism combine to poison them psychologically (Pierce, 1980). For example, in the USA, children often give up trying to succeed in school around 8 or 9 years old. Their negative experiences with the micro containments of racism from teachers and the curriculum trigger children's psychologically dropping out from school learning.

Racism creates the social-psychological dynamic of internalized racial oppression (IRO) ${ }^{2}$. This is a complex socialization process that teaches People of Color from early childhood to believe, accept, and live out negative, societal definitions of self and to carry out the inequitable relationships and roles designated by racism. It begins in the preschool years. Early childhood programs can get in the way of the "dance" of IRO (and IRS). This requires anti- bias / anti-discriminatory consciousness and practices in teachers and other staff, in ECCE programs, and systems (Urban et al., 2012, Vandenbroeck et al., 2012). Indeed, fostering resilience to racism is early childhood care and education's sphere of influence in the larger work of creating social and economic justice.

It involves fostering young children's positive individual and group identity, and building their sense of intelligence, worth, efficacy, and creativity.

The opposite side of the coin of IRO is internalized racial superiority, which teaches White people from early childhood to believe, accept, and live out racism's definitions of Whiteness. This complex socialization process allows white people to uncritically fit into and accept the societal roles of racial privilege. 
It means supporting children's belief in their right and ability to learn, and teaching them how to effectively interact with others and navigate the rules and demands of schools as an institution of the larger society. Interrupting the negative effects of internalized racial oppression also requires supporting families' beliefs in their children and their own ability to advocate for their children in the school system. For the most part, the Perry Preschool teacher's educational beliefs and practices encompassed all of these objectives, influenced as we were by the thinking of the Civil rights Movement that was taking place in the 1960s.

Perhaps, in the end, it was what the teachers did in relation to fostering the children's and families' resilience to the micro contaminants of racism and poverty, that most contributed to the positive longitudinal outcomes of the Perry Preschool. Is that the explanation for the unexpected trajectory of these outcomes? The initial stronger cognitive development and school success of children who attended the preschool waned and became increasingly similar to that of the children in the control group by third grade. It wasn't until high school that the Perry Preschool children began to display significantly greater success on a range of life as well as school factors. This certainly seems like resilience.

\section{Final Thoughts}

I have been asked about my path from the Perry Preschool to my AntiBias Education work of the past thirty years. My answer is that both came from the same place - my dreams, values and activism to build a more equitable, just society for all people. Becoming a teacher in the Perry Preschool project was one way to try to make a difference in the lives of children and families oppressed by racism and poverty. Moving to doing anti-bias education was also about choosing a way to intervene in the terrible harm that the "isms" do children. As I wrote in my first book, anti-bias education is "An active/activist approach to challenging prejudice, stereotyping, bias, and the 'isms'... It is necessary for each individual to actively intervene, to challenge and counter the personal and institutional behaviors that perpetuate oppression" (Derman-Sparks \& ABC Task Force, 1989, p.3). And, as I wrote in a more recent book, "The heart of anti-bias work is a vision of a world in which all children are able to blossom, and each child's particular abilities and gifts are able to flourish" (Derman-Sparks \& Edwards, 2010, p. 2).

I now realize that my (and other teachers) desire to make sure that the Perry children were developing a strong, positive identity (or self-concept, as 
we called it then) connects with the first of the four core goals of ant-bias education. ABE Goal One is about identity. It states, "Each child will demonstrate self-awareness, confidence, family pride, and positive social group identities". However, during the Perry Preschool years, it was the ideology of the Civil Rights Movement that motivated my concern for the children's identity, not the knowledge I later gained from the body of research about young chidlren's formation of racial identity and attitudes. The other three core anti-bias education goals address diversity, critical thinking about fairness and activism (Derman-Sparks \& Edwards, 2010). I wonder what the outcomes of attending the Perry Preschool might have been that if we had also paid attention to all four goals.

I also wonder what the research design might have looked like if it had investigated the children's and families' ideas, feelings, and behaviors related to the ABE goals. Would the basis of the PPP outcomes interesting trajectory (see the "resilience "section) become easier to understand if it had? Would we have found a connection between children's strong identity, critical thinking, and confidence to act to put right injustice, and their greater ability to negotiate the larger society as they moved into their young adult years? As Dr. Martin Luther King, Jr. wrote about the Civil Rights movement, "The real victory was what this period did to the psyche of the black man. We armed ourselves with dignity and self-respect [and] we straightened our backs up. And a man can't ride your back unless it is bent" (King, 1983, p. 47).

\section{References}

Baratz S., Baratz, C. , Lesser, G., Rist, R. , \& Vallentine, C. (1971). Challenging the myths: The schools, the Blacks, and the poor. Cambridge, Mass: Harvard Educational Review, Reprint Series \# 5.

Derman, L. (1963 - 1965). Small group activity reports. Unpublished manuscript. Ypsilanti, Michigan: Perry Preschool Project.

Derman-Sparks, L., \& the ABC Task Force. (1989). Anti-bias curriculum: Tools for empowering young children. Washington, DC: National Association for the Education of Young Children.

Derman-Sparks, L., \& J.O. Edwards. (2010). Anti-bias education for young children and ourselves. Washington, DC: National Association for the Education of Young Children. Deutsch, M. (1963). The disadvantaged child and the learning process. In A. H. Passow (Ed.), Education in depressed areas (pp. 147-162). New York: Columbia University Teachers College.

Duffy, M., \& Gibbs, A. (2012). Preschool education initiative for children from minority groups evaluation report. Retrieved from http://edenn.org/wp-content/uploads/2013/05/zdocs_Evaluation-Report-on-the-Pre-school-Education-Initiative-for-Children-from-Minority-Groups.pdf. 
Hofmann, M., Banet, B., \&Weikart, D. (1979). Young children in action. Ypsilanti, Michigan: High/Scope Press.

King, C. S. (Ed.). (1983). The words of Martin Luther King, Jr. New York, NY: Newmarket Press.

Pierce, C. M. (1980). Social trace contaminants: Subtle indicators of racism. In S. Withey, \& R. Abeles (Eds.),Television and social behavior: Beyond violence and children (pp. 249-257). Hillsdale, New Jersey: Lawrence Erlbaum.

Radin, N., \& Kamii, C. (1965). The child-rearing attitudes of disadvantaged negro mothers and some educational implications. Journal of Negro Education, 34 (2), 138-146. Rist, R. (1970). Student social class and teacher expectations: The self-fulfilling prophecy in ghetto education. Harvard Educational Review, 40 (3), 411-451.

Rosenthal, R., \& Jacobson, L. (1968, 1992, and 2003), Pygmalion in the classroom: Teacher expectation and pupils' intellectual development. Norwalk, CT: Crown House. Schweinhart, L, Montie, J, Xiang, Z., Barnbett, W.S., Belfield, C., \& Nores. M. (2005). Lifetime effects: The High/Scope Perry Preschool study through age 40. Ypsilanti, Michigan: High/Scope Press.

Shonkoff, J. (2007). Emotional \& cognitive development linked" NIERR's Preschool Matters. Online: http://nierr.org/psm/index.php/article=233.

Sonquist, H., \& Kamii, C. (1967). Applying some Piagetian concepts in the classroom for the disadvantaged. Young Children, 22, 231-246.

Urban, M., Vandenbroeck, M., Van Laere, K., Lazzari, A., \& Peeters, J. (2012). Towards competent systems in early childhood education and care. Implications for policy and practice. European Journal of Education, 47(4), 508-526.

Weikart, D., Kamii, C., \& Radin, N. (1964). Perry preschool project progress report. Ypsilanti, Michigan: Ypsilanti Public Schools.

Weikart, D., Rogers, L., Adcock., A., \& McClelland, D. (1970). The cognitively oriented curriculum: Final report, Vol. I \& II. Ypsilanti, Michigan: High/Scope Educational Research Foundation.

Weikart, D., Rogers, L. Adcock, C., \& McClelland, D. (1971). The cognitively oriented curriculum. Urbana, Illinois: University of Illinois.

Weikart, D. (1989). Quality preschool programs: A long-term social investment. Occasional Paper Number Five, Ford Foundation Project on Social Welfare and the American Future. New York, NY: Ford Foundation.

Weikart, D., \& Schweinhart, L. (2009). The High/Scope model of early childhood education. In J. Roopnarine, \& J. Johnson (Eds), Approaches to Early Childhood Education, (pp. 191-212). Columbus, OH: Prentice Hall.

\section{Author:}

Louise Derman-Sparks, Professor Emeritus

Pacific Oaks College

45 Eureka Street, Suite B

Pasadena

CA 91103

USA

Email: RLDSPARKS@aol.com 